\section{Metallionenivåer i blod fra pasienter med metall-mot-metall-hofteprotese}

\author{
ORIGINALARTIKKEL

\section{PAUL JOHAN HØL} \\ E-post:paul.hol@uib.no \\ Ortopedisk klinikk \\ Haukeland universitetssjukehus \\ og \\ Klinisk institutt 1 \\ Universitetet i Bergen \\ Han har bidratt med idé, design og utforming av manus. Han gjorde metallanalysene og tolkningen av \\ dataene, litteraturinnhenting og utarbeiding av selve teksten i manus. \\ Paul Johan Høl er forsker og senioringeniør. Han har doktorgrad i analytisk uorganisk kjemi og er \\ leder for Biomatlab ved Ortopedisk klinikk ved Haukeland universitetssjukehus. \\ Forfatteren har fylt ut ICMJE-skjemaet og oppgir ingen interessekonflikter.
}

\section{GEIR HALLAN}

Ortopedisk klinikk

Haukeland universitetssjukehus

og

Klinisk institutt 1

Universitetet i Bergen

Han har bidratt med datainnsamling (registerdata) samt revisjon av manus og har godkjent innsendt manusversjon.

Geir Hallan er spesialist i ortopedisk kirurgi, seksjonsoverlege og professor. Han er fagansvarlig for hofteproteser ved Nasjonalt register for leddproteser.

Forfatteren har fylt ut ICMJE-skjemaet og oppgir ingen interessekonflikter.

\section{KARI INDREKVAM}

Ortopedisk klinikk

Kysthospitalet i Hagevik

og

Klinisk institutt 1

Universitetet i Bergen

Hun har bidratt med idé og utforming av manuset. Hun gjorde de radiologiske målingene og innhentet journaldata. Hun deltok også i revisjon av manus og har godkjent innsendt versjon.

Kari Indrekvam er spesialist i ortopedisk kirurgi, sykehussjef, avdelingsoverlege og førsteamanuensis. Forfatteren har fylt ut ICMJE-skjemaet og oppgir ingen interessekonflikter. 


\section{BAKGRUNN}

BHR-protese (Birmingham hip resurfacing) er satt inn i hoften til 445 personer i Norge. Bivirkninger av metallfrigjøring fra metall-mot-metall-leddflater av kobolt-krom-legering kan forekomme. Målet med studien var å analysere frigjøringen av metallioner i løpet av de første fem årene etter operasjon hos pasienter med BHR-protese og å undersøke om det hadde sammenheng med kliniske komplikasjoner.

\section{MATERIALE OG METODE}

44 mannlige pasienter (medianalder 53 år) med BHR-protese satt inn ved Kysthospitalet i Hagevik i perioden oktober 2009-mai 2013 ble fulgt med blodprøver før implantasjon og tre måneder, ett år, tre år og fem år etter. Analyser av kobolt og krom i helblod ble utført. Klinisk vurdering av proteseleddet ble gjort ved funksjonsskåring.

\section{RESULTATER}

Metallionkonsentrasjonene $ø$ kte fra operasjonstidspunktet til ett år etter operasjon ( $p<$ o,o01), deretter holdt konsentrasjonene seg stabile. Etter fem år var mediankonsentrasjon (min.-maks.) av kobolt og krom henholdsvis 1,1 $\mu \mathrm{g} / \mathrm{L}(\mathrm{o}, 4-6,3 \mu \mathrm{g} / \mathrm{L})$ og 1,4 $\mu \mathrm{g} / \mathrm{L}(\mathrm{o}, 4-11,7 \mu \mathrm{g} / \mathrm{L})$ ved unilateral protese $(n=36)$, og henholdsvis $2,3 \mu \mathrm{g} / \mathrm{L}(1,6-28,5 \mu \mathrm{g} / \mathrm{L})$ og $2,6 \mu \mathrm{g} / \mathrm{L}(1,7-14,1$ $\mu \mathrm{g} / \mathrm{L})$ ved bilaterale proteser $(n=8)$. Fem pasienter ble reoperert, mens $ø$ vrige pasienter hadde god funksjon.

\section{FORTOLKNING}

Pasienter med BHR-protese fikk signifikant økning av kobolt og krom i blod ett til fem år etter kirurgi, men medianverdiene var likevel godt under grenseverdien på $7 \mu \mathrm{g} / \mathrm{L} \mathrm{som}$ indikerer $\emptyset \mathrm{kt}$ risiko for komplikasjoner.

Metall-mot-metall-hofteproteser (også kjent som MoM-proteser, metal-on-metal), der både leddhodet og hofteskålen er av metall, har vært i bruk siden 196o-årene. Protesene kom både som totalproteser med stamme, med enten store eller små hoder $(\leq 32 \mathrm{~mm})$, og som skallprotese uten stamme (1). Med en vanlig hofteprotese fjernes leddhodet og det meste av lårhalsen, og dette erstattes med en protese som har mindre hodediameter, og som festes inne i lårbenets marghule. Leddflatene er da oftest av metall-mot-polyetylen eller av keramikk. Med skallproteser, derimot, beholdes lårhalsen og det meste av leddhodet, og leddhodet får en ny overflate av metall. Det nye leddhodet har da samme størrelse som det opprinnelige og ledder mot en kopp laget av det samme materialet, vanligvis en koboltkrom-molybden-legering. Birmingham hip resurfacing-skallprotese, heretter omtalt som BHRprotese, ble utviklet i 1990-årene (figur 1) (2). Protesen skulle gi bedre stabilitet og bevegelighet $\mathrm{i}$ hofteleddet enn en konvensjonell protese, og redusere problemet med polyetylenslitasje og osteolyse (3). 


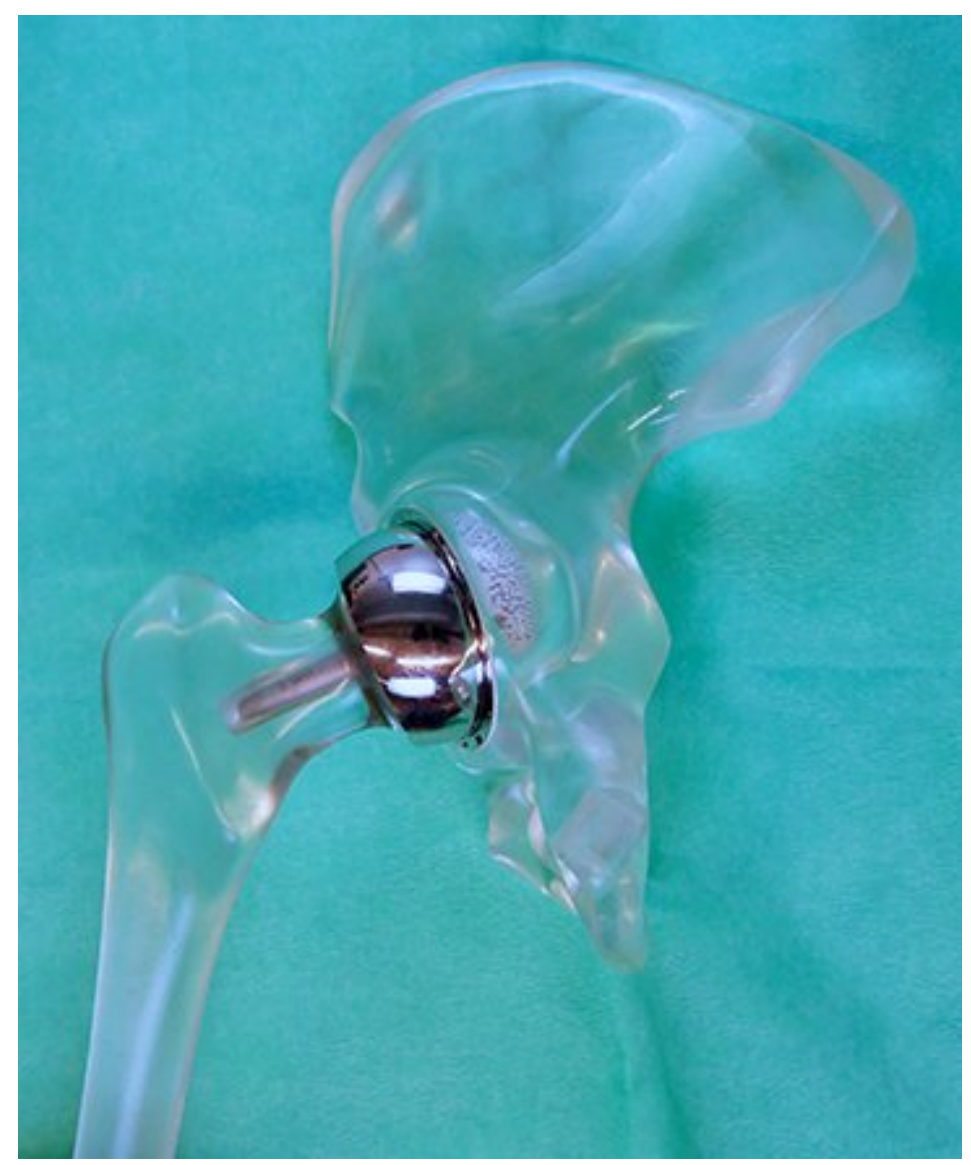

Figur 1 En Birmingham hip resurfacing-skallprotese (Smith and Nephew, Warwick, England), her satt inn i en hoftemodell, har metall-mot-metall-leddflater der «kopp» og «hode» består av en kobolt-krommolybden-legering med 66 \% Co, 26,5-3o \% Cr, 4,5-7,o \% Mo, <1 \% Ni, Mn og Fe, og < o,35 \% C, $i$ henhold til ISO-standard 5832. Bilderettigheter: Biomatlab, Haukeland universitetssjukehus.

Mellom 1987 og 2013 ble det ifølge Nasjonalt register for leddproteser satt inn 485 skallproteser i Norge, hvorav 466 BHR-proteser $(4,5)$. I flere land ble det oppdaget $ø k t$ forekomst av uheldige vevsreaksjoner som førte til krevende reoperasjon av metall-motmetall-proteser. Cystedannelse, ofte omtalt som pseudotumorer (6), aseptiske lymfocyttdominerte vaskulitt-assosierte lesjoner (ALVAL) (7) og uønskede vevsreaksjoner fra metallpartikler og ioner (ARMD, adverse reactions to metal debris) (8) er alle termer som har blitt brukt til å beskrive potensielt skadelige reaksjoner på metallslitasjeprodukter frigjort fra bæreflatene til slike proteser. Revisjonsraten for flere typer skallproteser var høy, dels på grunn av disse vevsreaksjonene, dels på grunn av andre komplikasjoner som lårhalsbrudd og proteseløsning (9). Disse komplikasjonene førte etter hvert til en rask reduksjon i bruken av slike proteser (2). I mange land, inkludert Norge, stoppet bruken av metall-motmetall-proteser helt i 2013.

Det er vist at det er en sammenheng mellom konsentrasjonen av metallioner i blodet og lokale vevsreaksjoner. Derfor er det anbefalt å måle metallionekonsentrasjonen i blodet hos utvalgte pasienter med metall-mot-metall-proteser, og i Norge er det satt en grenseverdi på $7 \mu \mathrm{g} / \mathrm{L}(10)$.

Systemiske effekter, slik som nevrologiske problemer, synsforstyrrelser, hørselstap, hukommelsessvikt og depresjon (11) samt kardiomyopati (12) er sjeldne, men rapportert hos pasienter med enkelte typer metall-mot-metall-proteser ved toksiske nivåer av spesielt kobolt (13).

Målet med denne studien var å analysere frigjøringen av metallioner i løpet av de første fem årene hos pasienter med BHR-protese. I tillegg ønsket vi å se om spormetallnivåene hadde sammenheng med kliniske komplikasjoner som smerte og redusert klinisk funksjon samt reoperasjoner. 


\section{Materiale og metode}

\section{ETIKK}

Studieprotokollen ble godkjent av regional komité for medisinsk og helsefaglig forskningsetikk (REK Vest, nummer 2010/2817). Skriftlig informert samtykke ble innhentet fra pasientene før første blodprøvetaking. Studien ble utført på avidentifiserte prøver.

\section{PASIENTER}

44 mannlige pasienter ved Kysthospitalet i Hagevik i perioden oktober 2009-mai 2013 ble inkludert og fulgt prospektivt (tabell 1). Medianalder var 53 år (min.-maks. 36-69 år). 36 pasienter fikk BHR-protese i den ene hoften, mens 8 hadde BHR-proteser i begge hoftene.

\section{Tabell 1}

Pasienter med unilateral og bilateral BHR-protese operert på Kysthospitalet i Hagevik i perioden oktober 2009-mai 2013. Median (min.-maks.) alder, protesestørrelse, helningsvinkel (inklinasjonsvinkel) på koppen og hoftefunksjonsskårer fem år etter operasjon.

\begin{tabular}{|lr|}
\hline Pasienter med unilat./bilat. BHR-protese, $\boldsymbol{n}$ & $\mathbf{3 6 / 8}$ \\
\hline Alder, år & $53(36-69)$ \\
\hline Hodestørrelse, mm & $54(46-64)$ \\
\hline Koppstørrelse, mm & $60(54-66)$ \\
\hline Helningsvinkel, $^{\circ}$ & $38(29-49)$ \\
\hline Harris' hofteskår $^{\text {Oxford-hofteskår }}$ & $96(61-100)$ \\
\hline
\end{tabular}

Den vanligste indikasjonen for operasjonen var primær artrose $(n=30)$ etterfulgt av sekundær artrose $(n=11)$.

\section{KLINISK VURDERING}

Klinisk vurdering av proteseleddet ble gjort med to validerte hofteskårer: Harris' hofteskår og Oxford-hofteskår. Harris' hofteskår ble registrert av lege. Denne består av kategoriene smerte, funksjon, bevegelse i leddet og deformitet av leddet. Skårene fra de ulike kategoriene summeres, og optimal skår er 100 poeng, mens o poeng er dårligste skår (14). Oxford-hofteskår bygger på et skjema med tolv spørsmål som måler funksjon og smerte, og som fylles ut av pasienten. Optimal skår er 12 poeng, mens dårligste skår er 6o poeng (15). Størrelsen på protesen ble individuelt tilpasset hver pasient. Det ble tatt røntgenbilder av bekkenet og hoften hos alle pasienter innen en uke etter operasjon, og koppens helningsvinkel ble målt i programvaren Sante DICOM Editor. Kliniske data om pasienter og protesekomponenter er hentet fra medisinsk journal ved sykehuset og kontrollert mot data fra Nasjonalt register for leddproteser.

\section{ANALYSE AV KOBOLT- OG KROMNIVÅER I HELBLOD}

Blodprøver ble samlet inn før kirurgi og deretter etter tre måneder, ett år, tre år og fem år.

Blod ble trukket fra en vene i underarmen med venekateter (Becton Dickinson Venflon Pro) og lagret ved $-2 \mathrm{O}^{\circ} \mathrm{C}$ i metallfrie polypropylenrør (VWR). Før analysen ble $1,5 \mathrm{~mL}$ helblod brutt ned i et mikrobølgeassistert system (Milestone 1200 Mega), tilsatt $3 \mathrm{~mL} 60$ \% ultraren $\mathrm{HNO}_{3}$ og $2 \mathrm{~mL} 30 \% \mathrm{H}_{2} \mathrm{O}_{2}$ (Merck) og fortynnet med dobbeltdestillert, avionisert vann (MilliQ).

Konsentrasjonen av kobolt og krom i helblod ble analysert med induktivt koblet plasmamassespektrometri (ICP-MS) (Thermo Scientific Element XR).

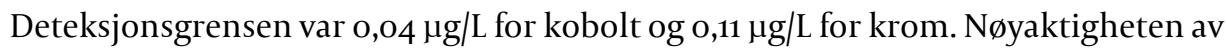


analysemetoden ble overvåket ved hjelp av et referansemateriale (Seronorm Trace Elements Whole Blood L-2).

\section{STATISTISK ANALYSE}

Dataene ble analysert ved hjelp av ikke-parametriske statistiske metoder med programvaren GraphPad Prism 8. Resultater oppgis her med medianverdi og laveste og høyeste verdi. Sammenligning mellom preoperative og postoperative metallkonsentrasjoner på pasientnivå ble gjort med Wilcoxons test for pardata. Korrelasjon mellom blodmetallnivået etter fem år og andre parametere (helningsvinkel, hodestørrelse, kliniske skårer) ble vurdert ved Spearmans rangkorrelasjonskoeffisient $\left(r_{\mathrm{sp}}\right)$ hos pasientene med unilateral protese. Fem blodprøver med krom-konsentrasjon under deteksjonsgrensen ble tildelt en verdi på halvparten av deteksjonsgrensen. Det statistiske signifikansnivået ble definert $\operatorname{som} p<0,05$.

\section{Resultater}

\section{BLODMETALLNIVÅR}

Konsentrasjonen av kobolt (figur 2a og tabell 2a) og krom (figur 2b og tabell 2b) i blod økte fra operasjonstidspunktet til ett år etter operasjon $(p<0,001)$ både for pasientene med unilateral og for pasientene med bilateral protese (tabell 2). Verken konsentrasjonen av kobolt $(p=0,057)$ eller $\operatorname{krom}(p=0,261)$ endret seg signifikant mellom ett og fem år etter operasjon.

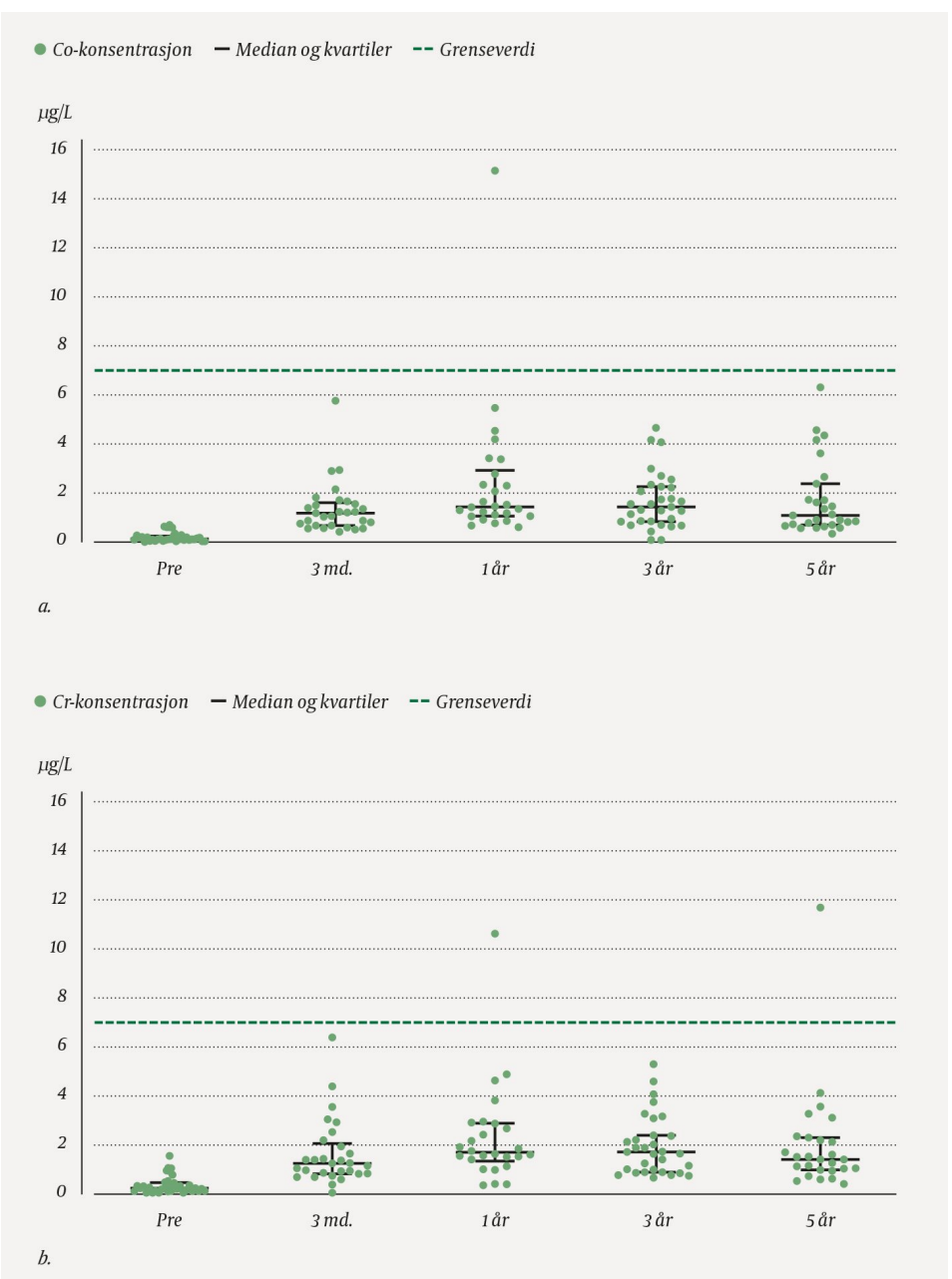

Figur 2 Konsentrasjon av a) kobolt (Co) og b) krom (Cr) i helblod ( $\mu \mathrm{g} / \mathrm{L})$ ved alle måletidspunkter (Pre $=$ preoperativt $(n=34)$, etter tre måneder $(n=29)$, etter ett å $(n=26)$, etter tre år $(n=31)$ og etter fem år $(n=27))$ hos pasienter med unilateral BHR-protese $(n=36)$. Svarte horisontale streker indikerer median og kvartiler. Stiplet linje viser grenseverdien i Norge ( $7 \mu \mathrm{g} / \mathrm{L}$ ). 


\section{Tabell 2a}

Antall blodprøver tilgjengelig og konsentrasjoner i helblod, representert ved median og laveste og høyeste verdi, av kobolt hos pasienter med unilaterale (Uni) og bilaterale (Bilat) BHR-proteser ved alle måletidspunktene (før operasjon og tre måneder, ett år, tre år og fem år etter). Kobolt i helblod $(\mu \mathrm{g} / \mathrm{L})$.

\begin{tabular}{|c|c|c|c|c|c|c|c|c|c|c|}
\hline & \multicolumn{2}{|c|}{ Preoperativt } & \multicolumn{2}{|c|}{$3 \mathrm{md}$. } & \multicolumn{2}{|c|}{1 år } & \multicolumn{2}{|c|}{3 år } & \multicolumn{2}{|c|}{5 år } \\
\hline & Uni & Bilat & Uni & Bilat & Uni & Bilat & Uni & Bilat & Uni & Bilat \\
\hline $\begin{array}{l}\text { Antall } \\
\text { blodprøver }\end{array}$ & 34 & 8 & 29 & 5 & 26 & 6 & 31 & 5 & 27 & 7 \\
\hline $\begin{array}{l}\text { Median } \\
\text { (min.-maks.) }\end{array}$ & $\begin{array}{c}0,14 \\
(0,02-0,71)\end{array}$ & $\begin{array}{c}0,84 \\
(0,05-2,75)\end{array}$ & $\begin{array}{c}1,19 \\
(0,43-5,78)\end{array}$ & $\begin{array}{c}3,72 \\
(0,46-14,98)\end{array}$ & $\begin{array}{c}1,45 \\
(0,62-15,16)\end{array}$ & $\begin{array}{c}3,20 \\
(1,17-20,16)\end{array}$ & $\begin{array}{c}1,45 \\
(0,10-4,68)\end{array}$ & $\begin{array}{c}3,25 \\
(2,15-15,26)\end{array}$ & $\begin{array}{c}1,10 \\
(0,36-6,32)\end{array}$ & $\begin{array}{c}2,29 \\
(1,55-28,53) \\
\end{array}$ \\
\hline
\end{tabular}

\section{Tabell 2b}

Antall blodprøver tilgjengelig og konsentrasjoner i helblod, representert ved median og laveste og høyeste verdi, av krom hos pasienter med unilaterale (Uni) og bilaterale (Bilat) BHR-proteser ved alle måletidspunktene (før operasjon og tre måneder, ett år, tre år og fem år etter). Krom i helblod ( $\mu \mathrm{g} / \mathrm{L})$.

\begin{tabular}{|c|c|c|c|c|c|c|c|c|c|c|}
\hline & \multicolumn{2}{|c|}{ Preoperativt } & \multicolumn{2}{|c|}{$3 \mathrm{md}}$. & \multicolumn{2}{|c|}{1 år } & \multicolumn{2}{|c|}{3 år } & \multicolumn{2}{|c|}{5 år } \\
\hline & Uni & Bilat & Uni & Bilat & Uni & Bilat & Uni & Bilat & Uni & Bilat \\
\hline $\begin{array}{l}\text { Antall } \\
\text { blodprøver }\end{array}$ & 34 & 8 & 29 & 5 & 26 & 6 & 31 & 5 & 27 & 7 \\
\hline $\begin{array}{l}\text { Median } \\
\text { (min.-maks.) }\end{array}$ & $\begin{array}{c}0,23 \\
(0,05-1,55)\end{array}$ & $\begin{array}{c}1,17 \\
(0,05-3,23)\end{array}$ & $\begin{array}{c}1,25 \\
(0,05-6,39)\end{array}$ & $\begin{array}{c}3,18 \\
(0,05-12,32)\end{array}$ & $\begin{array}{c}1,70 \\
(0,36-10,63)\end{array}$ & $\begin{array}{c}2,93 \\
(1,34-11,07)\end{array}$ & $\begin{array}{c}1,71 \\
(0,66-5,30)\end{array}$ & $\begin{array}{c}3,05 \\
(2,71-10,07)\end{array}$ & $\begin{array}{c}1,41 \\
(0,40-11,7)\end{array}$ & $\begin{array}{c}2,56 \\
(1,65-14,07)\end{array}$ \\
\hline
\end{tabular}

Fem pasienter hadde kobolt- og/eller kromkonsentrasjon over den nasjonale grenseverdien på $7 \mu \mathrm{g} / \mathrm{L}$ ved minst ett av måletidspunktene postoperativt. Tre av disse hadde bilateral protese. Den høyeste koboltkonsentrasjonen som ble observert, var på $28,5 \mu \mathrm{g} / \mathrm{L}, \mathrm{og}$ hos den samme pasienten fant vi også den høyeste kromkonsentrasjonen $(14,1 \mu \mathrm{g} / \mathrm{L})$.

Det var korrelasjon $\left(r_{\mathrm{Sp}}=0,77 ; p<0,001\right)$ mellom konsentrasjonen av kobolt og krom $\mathrm{i}$ helblod hos pasienter med unilateral protese fem år etter operasjon (figur 3 ). 
- Konsentrasjon etter fem år

- Trendlinje -- $95 \% \mathrm{KI}$

\section{$\operatorname{Cr}(\mu g / L)$}

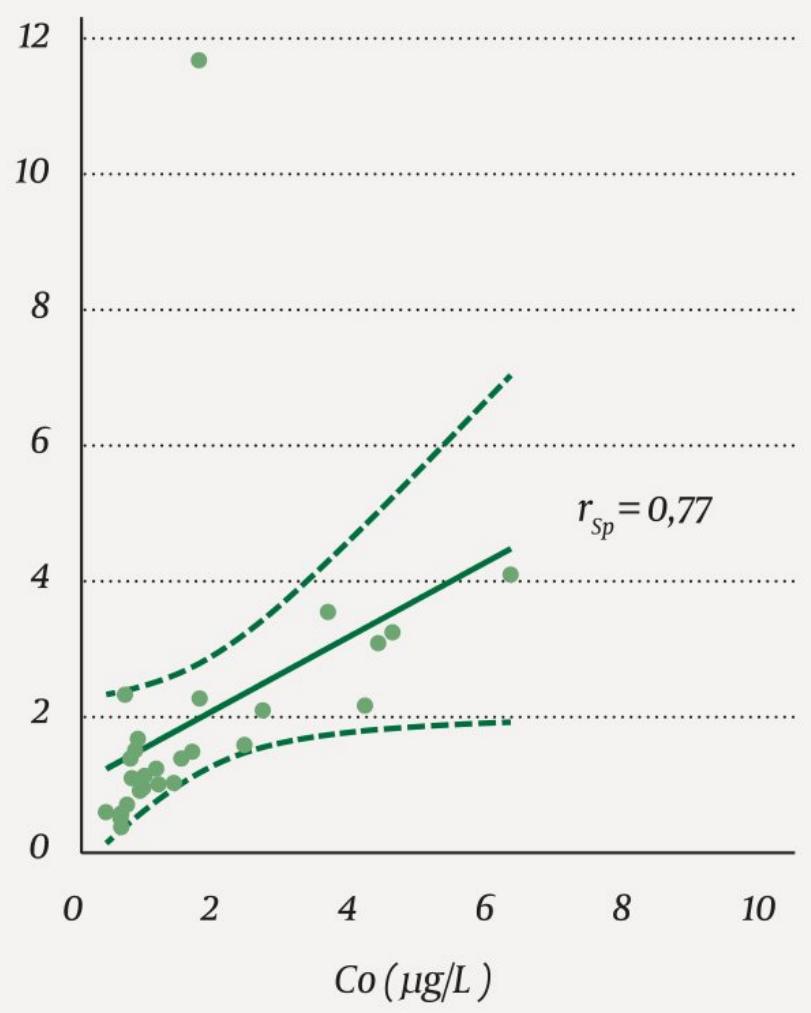

Figur 3 Korrelasjonsplott av konsentrasjonen av kobolt (Co) og krom (Cr) fem år etter operasjon for pasientene med unilateral protese $(n=27)\left(r_{5 p}=0,77 ; p<0,001\right)$. Heltrukket linje viser trend, stiplete linjer viser $95 \%$ konfidensintervall. $r_{s p}=$ Spearmans rangkorrelasjonskoeffisient.

\section{KLINISKE FUNN}

Harris' hofteskår bedret seg fra 6o poeng (36-91 poeng) preoperativt til 96 poeng (61-10o poeng) etter fem år. Median Oxford-hofteskår forbedret seg fra 33 poeng (21-45 poeng) til 13 poeng (12-31 poeng) fem år etter inngrepet.

Vi fant ingen korrelasjon mellom de kliniske skårene hos pasientene med unilateral protese og metallnivåene i blod fem år etter operasjon. De fem pasientene med metallnivåer over grenseverdien på $7 \mu \mathrm{g} / \mathrm{L}$ hadde median Harris' hofteskår på 97 poeng (93-100 poeng) fem år etter inngrepet.

Det var fem reoperasjoner i løpet av femårsperioden, på grunn av smerter $(n=3)$, proteseløsning $(n=1)$ og pseudotumor $(n=1)$, der alle pasientene hadde metallnivåer under grenseverdien på $7 \mu \mathrm{g} / \mathrm{L}$.

\section{PROTESEHODESTØRRELSE, HELNINGSVINKEL OG KORRELASJON MED METALLNIVA}

Median hodestørrelse var $54 \mathrm{~mm}$ (46-64 mm), og bare én femurkomponent var mindre enn $50 \mathrm{~mm}$ (tabell 1 ).

Median helningsvinkel for protesekoppene var $38^{\circ}$, og vinkelen varierte mellom $29^{\circ}$ og $49^{\circ}$, hvilket er innenfor anbefalt område i faglitteraturen.

Vi fant ingen statistisk signifikant korrelasjon mellom metallioneverdiene fem år etter operasjon og protesens hodestørrelse eller koppens helningsvinkel. 


\section{Diskusjon}

I denne studien nådde pasientene en topp i metallkonsentrasjon i blod etter ett år. Deretter holdt verdiene seg på dette nivået ved målinger etter tre og fem år. Medianverdiene er godt under den norske grenseverdien på $7 \mu \mathrm{g} / \mathrm{L}$ og er sammenlignbare med nivåene rapportert i andre studier av pasienter med BHR-protese $(2,16)$. I en multisenterstudie med 416 pasienter med BHR-protese fant man en mediankonsentrasjon i helblod på 1,4 $\mu \mathrm{g} / \mathrm{L}$ for

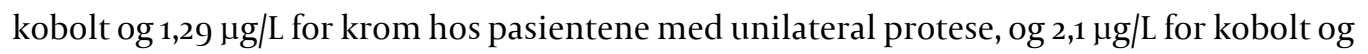
$2,3 \mu \mathrm{g} / \mathrm{L}$ for krom hos pasientene med bilateral protese (17).

Bare fem pasienter i vår studie hadde verdier som var høyere enn den norske grenseverdien. Alle fem hadde gode kliniske resultater vurdert ved hofteskårer, men de anses å være i risikosonen for å utvikle pseudotumor og følges derfor tett.

Metallionenivå i blod brukes som en indikator for mulige komplikasjoner knyttet til leddprotesen, men sensitivitet og spesifisitet i så måte er relativt lav (18), hvilket til en viss grad illustreres av våre funn.

I vår studie ble 5 av 44 pasienter reoperert, og 4 av de reopererte pasientene fikk skiftet protesen uten objektive funn som tydet på pseudotumor. Alle de reopererte pasientene hadde metallnivåer under grenseverdien på $7 \mu \mathrm{g} / \mathrm{L}$.

Samlet revisjonsgrad av skallproteser (hovedsakelig BHR-proteser) er vist å ligge på gjennomsnittlig $5 \%$ (95\% konfidensintervall 3,o til 7,0 \%) etter fem år i Norge (5). Til sammenligning hadde standard totale hofteproteser en lavere revisjonsrisiko på 3,8 \% (95\% $\mathrm{KI}_{3,6}$ til 4,0 \%) etter fem år (5).

Det er få langtidsstudier som dokumenterer levetiden av BHR-proteser over ti år. I en retrospektiv studie av 95 personer med BHR-protese fant man en samlet revisjonsgrad på $12 \%$ med ti års oppfølging (16). Revisjonsgraden var høyere hos kvinner (16\%) enn hos menn (7\%). Det australske registeret rapporterte 6,6\% revisjon av BHR-proteser med ti års oppfølging. Andre skallproteser, slik som ASR-protesen (articular surface replacement, DePuy), har hatt langt dårligere resultater, med opptil 30 \% reoperasjoner etter ti år, trolig på grunn av designforskjeller som gir økt metallfrigjøring (19).

Det er beskrevet risikofaktorer for å utvikle pseudotumorer og andre vevsreaksjoner hos pasienter med metall-mot-metall-hofteproteser. I tillegg til pasienter med forhøyede konsentrasjoner av kobolt og krom i blod har kvinner og pasienter med mindre femurhodestørrelser ( $<50 \mathrm{~mm}$ diameter) og høy helningsvinkel $\left(>50^{\circ}\right)$ på protesekoppen $\emptyset \mathrm{kt}$ risiko (20). Det har vært hevdet at lokalisert kantslitasje mellom hode og kopp ved høy helnings- eller anteversjonsvinkel på koppen gir en økning av metallionenivåer (8). I vår studie er både kopp-posisjonering og komponentstørrelse innenfor akseptable grenser. Kun én protese hadde hodestørrelse mindre enn $50 \mathrm{~mm}$.

I Norge anbefaler Nasjonal kompetansetjeneste for leddproteser og hoftebrudd at sykehusene følger opp pasienter med alle typer metall-mot-metall-proteser som har hodediameter over $32 \mathrm{~mm}$, regelmessig gjennom protesens levetid (10).

Kontrollhyppigheten varierer med pasientens kjønn (kvinner følges tettere), leddhodets størrelse (små leddhoder følges tettere) og protesens dokumenterte langtidsresultater. Vanlige røntgenbilder suppleres med måling av metaller i fullblod, og dersom det er funn ved disse undersøkelsene eller klinisk mistanke (smerter, palpabel oppfylling, reduksjon i funksjon), suppleres det med MR-undersøkelse, alternativt ultralyd (5).

Grenseverdier for konsentrasjon av kobolt og krom i blod som indikerer økt risiko for vevsreaksjoner og reoperasjon, har vist seg vanskelige å fastsette, og det er ingen konsensus om disse grensene (17). I de fleste europeiske land, inkludert Norge, er grenseverdien satt til $7 \mu \mathrm{g} / \mathrm{L}(10)$. Noen har valgt lavere grenseverdi, helt ned i $3 \mu \mathrm{g} / \mathrm{L}$ (5). Lavere grense gir naturlig nok dårligere spesifisitet. Dette er en pågående diskusjon.

$\emptyset \mathrm{kt}$ pseudotumorvolum, dårligere hoftefunksjonsskår og bilateral metall-mot-metallprotese har også blitt assosiert med fremtidig reoperasjon (5). Det trengs derfor ytterligere 
kartlegging av sammenhengen mellom metallionenivå og biologiske årsaksmekanismer for utvikling av vevsreaksjoner.

En svakhet med studien er at kun menn ble inkludert. Ved studiestart var det vist at kvinner hadde dårligere resultater med slike proteser, og protesen ble bare benyttet på menn i inklusjonsperioden. Styrken er at det er en prospektiv studie med preoperative målinger og flere postoperative oppfølginger av en kohort fra samme sykehus. Kohorten utgjør ca. 10 \% av alle pasienter som har fått BHR-protesen i Norge.

\section{HOVEDFUNN}

En gruppe pasienter som fikk BHR-protese, hadde signifikant økning i median blodkonsentrasjon av kobolt og krom ett til fem år etter operasjonen.

Fem pasienter hadde metallioneverdier over grenseverdien på $7 \mu \mathrm{g} / \mathrm{L}$, men var symptomfrie. Fem reopererte, symptomatiske pasienter hadde metallioneverdier under grenseverdien på $7 \mu \mathrm{g} / \mathrm{L}$.

Metallionekonsentrasjon alene gir ikke tilstrekkelig informasjon til å predikere nødvendigheten av reoperasjon.

\section{LITTERATUR:}

1. Head WC. The Wagner surface replacement arthroplasty. Orthop Clin North Am 1982; 13: 789-97. [PubMed]

2. Holland JP, Langton DJ, Hashmi M. Ten-year clinical, radiological and metal ion analysis of the Birmingham Hip Resurfacing: from a single, non-designer surgeon. J Bone Joint Surg Br 2012; 94: 471-6. [PubMed][CrossRef]

3. Logishetty K, van Arkel RJ, Ng KCG et al. Hip capsule biomechanics after arthroplasty: the effect of implant, approach, and surgical repair. Bone Joint J 2019; 101-B: 426-34. [PubMed][CrossRef]

4. Nasjonalt Kompetansesenter for Leddproteser. Årsrapport 2018. Bergen: Helse Bergen HF, Ortopedisk klinikk, Haukeland universitetssjukehus, 2018.

http://nrlweb.ihelse.net/Rapporter/Rapport2018.pdf Lest 27.10.2020.

5. Pijls BG, Meessen JMTA, Tucker Ket al. MoM total hip replacements in Europe: a NORE report. EFORT Open Rev 2019; 4: 423-9. [PubMed][CrossRef]

6. Pandit H, Glyn-Jones S, McLardy-Smith P et al. Pseudotumours associated with metal-on-metal hip resurfacings. J Bone Joint Surg Br 2008; 90: 847-51. [PubMed][CrossRef]

7. Langton DJ, Sidaginamale RP, Joyce TJ et al. Aseptic lymphocyte-dominated vasculitis-associated lesions are related to changes in metal ion handling in the joint capsules of metal-on-metal hip arthroplasties. Bone Joint Res 2018; 7:388-96. [PubMed][CrossRef]

8. Langton DJ, Jameson SS, Joyce TJ et al. Early failure of metal-on-metal bearings in hip resurfacing and large-diameter total hip replacement: A consequence of excess wear. J Bone Joint Surg Br 2010; 92: 38-46. [PubMed][CrossRef]

9. Matharu GS, Pandit HG, Murray DW. Poor survivorship and frequent complications at a median of 1o years after metal-on-metal hip resurfacing revision. Clin Orthop Relat Res 2017; 475:304-14.

[PubMed][CrossRef]

10. Oppfølging av pasienter med metall-på-metall hofteproteser. Anbefaling fra Nasjonalt Register for Leddproteser. http://nrlweb.ihelse.net/Anbefalinger/Metall\%2opå\%2ometall.pdf Lest 20.4.2020.

11. Green B, Griffiths E, Almond S. Neuropsychiatric symptoms following metal-on-metal implant failure with cobalt and chromium toxicity. BMC Psychiatry 2017; 17:33. [PubMed][CrossRef]

12. Mosier BA, Maynard L, Sotereanos NG et al. Progressive cardiomyopathy in a patient with elevated cobalt ion levels and bilateral metal-on-metal hip arthroplasties. Am J Orthop (Belle Mead NJ) 2016; 45: 
E132-5. [PubMed]

13. Pelclova D, Sklensky M, Janicek P et al. Severe cobalt intoxication following hip replacement revision: clinical features and outcome. Clin Toxicol (Phila) 2012; 50: 262-5. [PubMed][CrossRef]

14. Harris WH. Traumatic arthritis of the hip after dislocation and acetabular fractures: treatment by mold arthroplasty. An end-result study using a new method of result evaluation. J Bone Joint Surg Am 1969; 51: 737-55. [PubMed][CrossRef]

15. Dawson J, Fitzpatrick R, Carr A et al. Questionnaire on the perceptions of patients about total hip replacement. J Bone Joint Surg Br 1996; 78: 185-90. [PubMed][CrossRef]

16. Hartmann A, Lützner J, Kirschner S et al. Do survival rate and serum ion concentrations 10 years after metal-on-metal hip resurfacing provide evidence for continued use? Clin Orthop Relat Res 2012; 470:3118-26. [PubMed][CrossRef]

17. Matharu GS, Berryman F, Judge A et al. Blood metal ion thresholds to identify patients with metalon-metal hip implants at risk of adverse reactions to metal debris: An external multicenter validation study of birmingham hip resurfacing and corail-pinnacle implants. J Bone Joint Surg Am 2017; 99: 1532-9. [PubMed][CrossRef]

18. Hart AJ, Sabah SA, Bandi AS et al. Sensitivity and specificity of blood cobalt and chromium metal ions for predicting failure of metal-on-metal hip replacement. J Bone Joint Surg Br 2011; 93: 1308-13. [PubMed][CrossRef]

19. Hip, Knee \& Shoulder Arthroplasty: 2019 Annual Report. Adelaide: Australian Orthopaedic Association National Joint Replacement Registry, 2019. https://aoanjrr.sahmri.com/annual-reports-2019 Lest 10.3.2020.

20. The safety of metal-on-metal joint replacements with a particular focus on hip implants. Luxembourg: Scientific Committee on Emerging and Newly Identified Health Risks (SCENIHR), 2014. https://ec.europa.eu/health/sites/health/files/scientific_committees/emerging/docs/scenihr_o_o42.pd f Lest 14.8.2019.

Publisert: 11. januar 2021. Tidsskr Nor Legeforen. DOI: 10.4045/tidsskr.20.0344

Mottatt 17.4.2020, første revisjon innsendt 16.9.2020, godkjent 20.11.2020.

(C) Tidsskrift for Den norske legeforening 2020. Lastet ned fra tidsskriftet.no 